\title{
PATTERN OF INFRASTRUCTURE-INDUCED SOCIO-ECONOMIC DEVELOPMENT IN RURAL SETTLEMENTS OF NIGER STATE, NIGERIA ADEDAYO, A. ${ }^{1}$ and ${ }^{*}$ SULYMAN, A. $0{ }^{2}$ http://dx.doi.org/10.4314/ejesm.v6i6.11S
}

Received 15th August 2013; accepted 12th November 2013

\begin{abstract}
This study analyses the variation in infrastructure - induced pattern of socio - economic development among some selected rural settlements in Niger state of Nigeria. To achieve this aim, twenty-two rural settlements were randomly selected and their scores on selected infrastructure were used to ascertain the pattern of socio - economic development. The relative strength of the factors was determined by factors analysis. The results revealed variation in infrastructure - induced pattern of development. Factor analysis revealed five factors that account for $85.82 \%$ of the total variance. Factor 1 which is Institutional infrastructure indicated high positive scores on four settlements namely Paiko, Agwara, Wushishi and Maikunkele. Factor 2 which is the Households' infrastructure loaded positively high in six settlements namely Enagi, Gawu Babangida, Lemu, Sabo Wuse, Doko and Nasko. Factor 3 is Welfare infrastructure shows high positive scores on three settlements namely Kuta, Bangi and Doko. Accessibility factor is indicated in factor 4 with high positive scores on four settlements namely Gbajibo, Enagi, Paiko and Rafin Gora. Lastly, Factor 5, which has been termed Road density, shows high positive scores on three settlements. These are Tunga Magajiya, Doko and Maikunkele. The study recommends provision of rural infrastructure and their proper maintenance to improve the standard and quality of life of rural residents in the state.
\end{abstract}

Key words: Rural Infrastructure, Factor scores, Variation, Pattern, Rural settlements and Socio-economic development.

\section{Introduction}

The importance of infrastructure to rural socio-economic life, according to Egunjobi (1987) can be seen from three perspectives. First, they stimulate economic activities. Second, they promote societal welfare of people and third, they prevent rural depopulation. Also stressing the importance of provision of infrastructure in rural development, Madu (2007) observes that although diverse indicators are used to measure the level of rural development in a community, access to infrastructure is the most satisfactory yardstick of such assessment. This is because it shows at a glance the extent to which a community enjoys social amenities. Also, the importance of infrastructure lies in its capacity to help sustain daily activities, quality of life, and an economic base in rural settlements.

\footnotetext{
${ }^{1}$ Department of Geography \& Environmental Management, University of Ilorin, Ilorin Nigeria

$2^{2 *}$ Department of Urban \& Regional Planning, Federal

University of Technology, Minna Nigeria

*Corresponding author: sulymanlance@gmail.com
}

It has been noted that the spatial variation in availability and access to rural infrastructure results in spatial disparities in living standard both within and between regions and localities (Adedayo, 1988; Madu, 2007). The existence of disparities in living standards therefore makes the analysis of the patterns of rural development imperative in order to identify areas of deprivation. The analysis is particularly important in Nigeria, where inadequate and non-functional rural infrastructure is the major characteristic of the rural settlements.

In terms of the roles that rural settlements play in the economy of a nation, infrastructure is meant to enhance the productive capacity and the quality of life of the rural areas and inhabitants. It is in this way that the nation can actually achieve what might be regarded as the essence of rural development in the spatial economy with its 
characteristic rural-urban dichotomy (Areola, 1987). Infrastructure is often regarded as the underlying foundation or basic framework of a system (Abumere, et al., 2002). Therefore, programmes for poverty reduction in rural areas or indeed for overall rural development cannot succeed unless supported by infrastructure. Hence, access to infrastructure is usually used as a sensitive measure of poverty and rural performance. Madu (2007) supporting the above assertion reports that availability of rural infrastructure can be effectively used as proxy indicators of the level of rural development in Nigeria.

Basically, rural development is concerned with raising the quality of life of the low-income population living in rural areas on a selfsustaining basis, through a fundamental transformation of the rural mode of production. It entails the total transformation of the rural component of the nation's mode of production. This involves a transformation of not only production technology and organization but also social relationships and social basis for coordinating the rural population. Thus, when viewed as socio-economic transformation, rural development means the restructuring of the Nigerian rural economy so as to lift it from being a peasant, subsistence agricultural economy to a modern agro-industrial economy capable of raising and sustaining the quality of life in our rural areas (Gana, 1987). However, Olujimi and Olanrewaju (2003) are of the opinion that provision of rural infrastructure that will facilitate the production, distribution and consumption activities as well as enhance the quality of rural life is central to rural transformation.
Infrastructural delivery arrangement in the rural settlements in Nigeria both in quality and quantum are far from satisfactory. Consequently, spatial variation in availability and access to rural infrastructure has resulted in spatial disparities in socio-economic development both within and between regions and locations. The extent to which infrastructure provision impacts on socioeconomic development of rural settlements in the country becomes necessary so as to come up with strategies for sustainable infrastructural delivery. It is against this background that this paper analyses the variation in infrastructure-induced pattern of socio-economic development among the rural settlements in Niger State of Nigeria.

\section{Study Area}

Niger state is located between latitudes $8^{\circ} 20^{\prime}$ $\mathrm{N}$ and $11^{\circ} 30^{\prime} \mathrm{N}$ and longitude $3^{\circ} 30^{\prime} \mathrm{E}$ and $7^{\circ} 20^{\prime} \mathrm{E}$. The state is situated in the North Central geopolitical zone and shares its borders with the Republic of Benin (West), Zamfara State (North), Kebbi (North-West), Kogi (South), Kwara (South-West), Kaduna (North-East) and the Federal Capital Territory FCT (South-East) (Niger State Government, 2004). Figure 1 shows the location of Niger state in Nigeria. The state covers a total land area of about 76,000 sq.km, or about 9 percent of Nigeria's total land area. This makes the state the largest in the country (Baba, 1993, Online Nigeria, 2003.). At inception in 1976, the state had only eight Local Government Areas (LGAs), however, with the series of state and local government creation exercises and boundary adjustments between 1979 and 1996; the number of LGAs in the state has increased to twenty-five. 


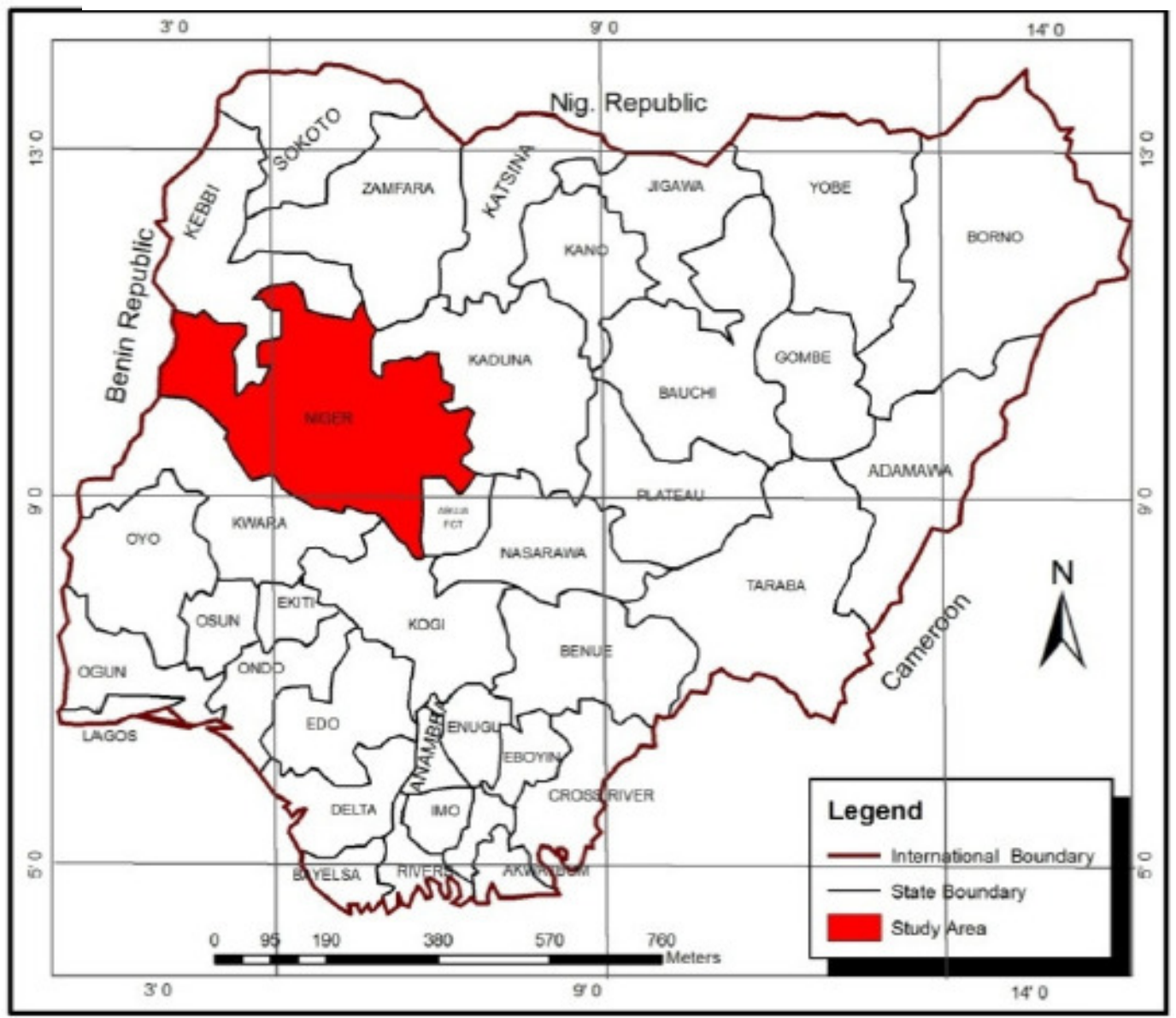

Figure 1 Map of Nigeria showing Niger State

Source Federal Ministry of Lands, Housing and Urban Development, Abuja

\section{Methodology}

A multistage sampling technique was adopted for the selection of settlements for the study. In Niger State, there are 25 local government areas, however, Chanchanga, Bida and Suleja local government areas have been excluded because they are municipal local government areas which cannot be regarded as rural. Thus, only the remaining 22 local government areas were considered for the purpose of selecting the rural settlements for this study.

The 22 local government areas were further stratified into two: namely completely rural local government areas and partially rural local government areas. The completely rural local government areas as defined here are local government areas consisting of all settlements having population below 20,000 including their headquarters, while the partially rural local government areas have only their headquarters with population of more than 20,000 while the other settlements in the local government areas have population of less 20,000 .

The selection of settlements was done by ranking all the settlements in each local government in descending order and selecting the first settlement with population of less than 20,000. In all, a total of 22 settlements were selected traversing 22 local government areas. The locations of the settlements selected are shown in Figure 2 


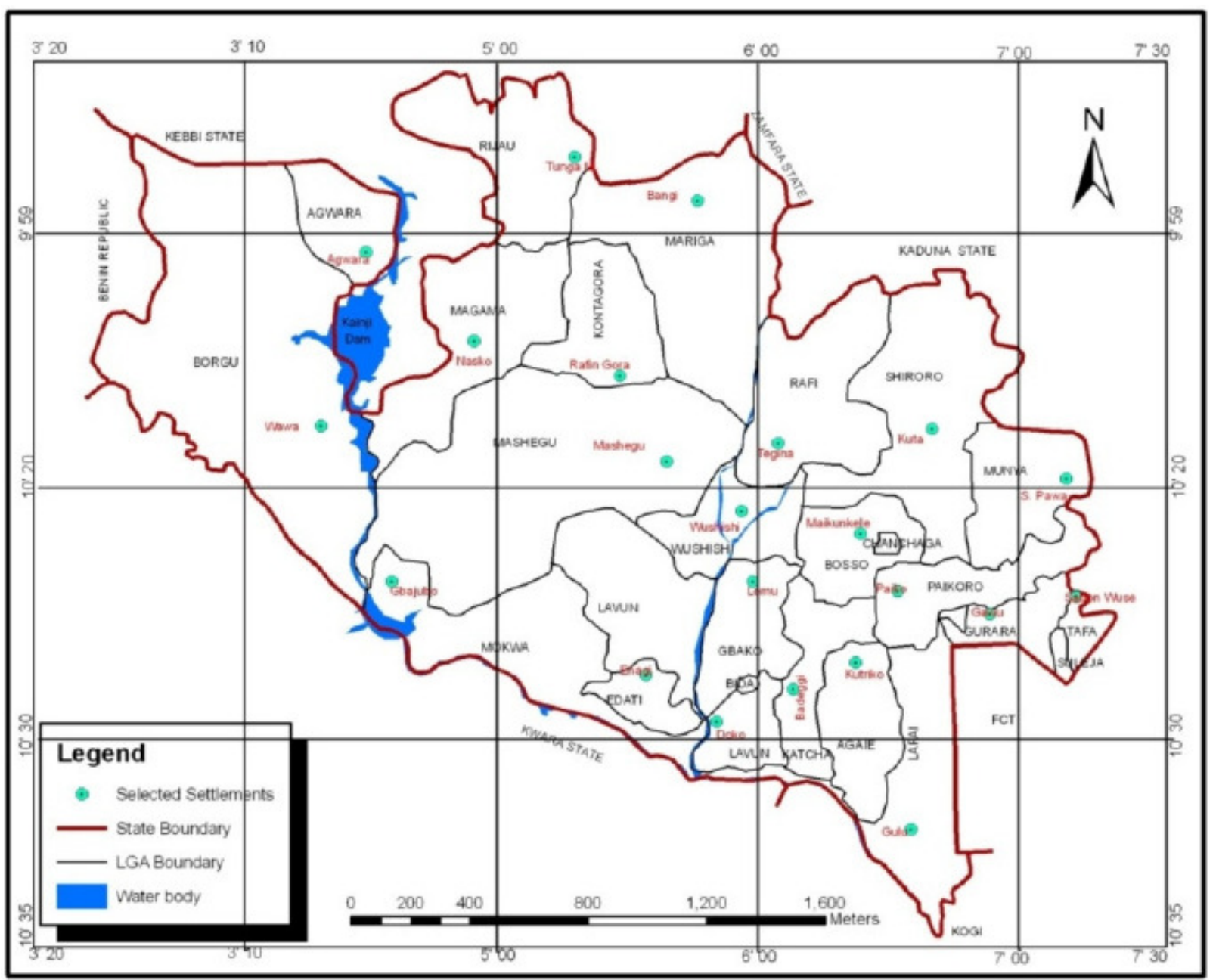

Figure 2 The locations of the settlements selected for the study Source: Ministry of Lands and Housing, Minna

For the administration of questionnaires, 5\% of the households in each of the selected rural settlements was selected for interview using systematic random sampling method to pick the respondents in each settlement. The total number of questionnaires administered was 1,792. This was derived from estimated number of households using average rural household size of 5 (National Bureau of Statistics, 2006). Factor analytical technique was used to identify the significant variables that accounted for variation in infrastructure-induced pattern of socio-economic development among the selected rural settlements.
Results and Discussions

Variation in Infrastructure-induced Socioeconomic Development

Factor analysis was used to reduce the size of the original data set so as to extract a small set of factors which significantly account for most of the variance in the original set. Consequently, a factor analysis with varimax rotation was applied to the 20x20 data matrix involving infrastructural and socio-economic variables as shown in Table 1.

Altogether, five factors with Eigen values greater than one were extracted, which together account for $85.821 \%$ of the total variance in the 
input matrix in the original twenty (20) variables. Table 2 indicates the relative importance of the factors with Eigen values greater than one. The factors encompass all the variables instrumental to variation in the pattern of infrastructural-induced socio-economic development of the settlements.

Table 1 List of Infrastructural and Socio-Economic Variables

\begin{tabular}{cl}
\hline Variables & Definition \\
\hline $\mathrm{X}_{1}$ & Road density in $\mathrm{Km}^{2}$ \\
$\mathrm{X}_{2}$ & Number of health facilities per settlement \\
$\mathrm{X}_{3}$ & Distance in Km travelled to reach the health facilities \\
$\mathrm{X}_{4}$ & Number of educational facilities per settlement \\
$\mathrm{X}_{5}$ & Distance in Km travelled to reach the educational facilities \\
$\mathrm{X}_{6}$ & Number of water facilities per settlement \\
$\mathrm{X}_{7}$ & Distance in Km travelled reach the water facilities \\
$\mathrm{X}_{8}$ & Number of settlements connected to National Grid ( electricity) \\
$\mathrm{X}_{9}$ & Percentage of households with formal education \\
$\mathrm{X}_{10}$ & Percentage of households with refrigerator \\
$\mathrm{X}_{11}$ & Number of administrative facilities per settlement \\
$\mathrm{X}_{12}$ & Number of social institutions per settlement \\
$\mathrm{X}_{13}$ & Number of communication facilities per settlement \\
$\mathrm{X}_{14}$ & Percentage of households with non-formal education \\
$\mathrm{X}_{15}$ & Percentage of households with radio \\
$\mathrm{X}_{16}$ & Percentage of households with TV set \\
$\mathrm{X}_{17}$ & Percentage of households with electric iron \\
$\mathrm{X}_{18}$ & Percentage of households with electric fan \\
$\mathrm{X}_{19}$ & Number of financial institutions per settlement \\
$\mathrm{X}_{20}$ & Number of recreational facilities per settlement \\
\hline
\end{tabular}

Table 2 Relative Importance of Factors with Eigen Values Greater than one.

\begin{tabular}{cccc}
\hline Factors & Eigen Value & \% of Total Variance & $\begin{array}{c}\text { Cumulative \% of Total } \\
\text { Variance }\end{array}$ \\
\hline 1 & 5.022 & 25.109 & 25.109 \\
2 & 4.675 & 23.373 & 48.482 \\
3 & 3.522 & 17.610 & 66.092 \\
4 & 2.748 & 13.741 & 79.833 \\
5 & 1.198 & 5.988 & 85.821 \\
\hline
\end{tabular}

The matrix of rotated factor loading is presented in Table 3 while the most important loading for each factor is indicated in Table 4. Factor 1 which accounts for $25.109 \%$ of the total variance loads highly in a positive direction on availability of communication facilities (0.879), financial (0.869) and social institutions (0.859). Other variables that load positively on this factor are availability of administrative facilities (0.550) and households with formal education (0.769). The availability of infrastructure that are generally regarded as Institutional infrastructure in the selected settlements is articulated by this factor and can therefore be termed Institutional infrastructure. 
Table 3 Rotated Factor Loadings

\begin{tabular}{cccccc}
\hline Variable & Factor 1 & Factor 2 & Factor 3 & Factor 4 & Factor 5 \\
\hline $\mathrm{X}_{13}$ & $\underline{0.879}$ & 0.088 & 0.195 & 0.172 & -0.023 \\
$\mathrm{X}_{19}$ & $\underline{0.869}$ & 0.137 & 0.186 & 0.131 & -0.133 \\
$\mathrm{X}_{12}$ & $\underline{\underline{0.859}}$ & 0.146 & 0.238 & 0.218 & -0.073 \\
$\mathrm{X}_{9}$ & $\underline{\underline{0.769}}$ & 0.392 & 0.190 & -0.212 & -0.010 \\
$\mathrm{X}_{14}$ & $\underline{-0.729}$ & -0.348 & -0.119 & 0.268 & 0.068 \\
$\mathrm{X}_{11}$ & $\underline{0.550}$ & 0.493 & 0.411 & -0.057 & 0.002 \\
$\mathrm{X}_{18}$ & 0.254 & $\underline{0.859}$ & 0.218 & 0.198 & -0.167 \\
$\mathrm{X}_{17}$ & 0.379 & $\underline{0.855}$ & 0.261 & -0.006 & 0.032 \\
$\mathrm{X}_{15}$ & 0.362 & $\underline{0.796}$ & 0.292 & -0.128 & -0.067 \\
$\mathrm{X}_{8}$ & -0.088 & $\underline{0.773}$ & -0.078 & 0.116 & 0.029 \\
$\mathrm{X}_{16}$ & 0.568 & $\underline{0.734}$ & 0.300 & -0.010 & -0.136 \\
$\mathrm{X}_{10}$ & 0.556 & $\underline{0.691}$ & 0.361 & -0.064 & -0.018 \\
$\mathrm{X}_{20}$ & 0.168 & 0.299 & $\underline{0.895}$ & -0.063 & 0.086 \\
$\mathrm{X}_{6}$ & 0.232 & 0.423 & $\underline{0.840}$ & -0.081 & -0.029 \\
$\mathrm{X}_{2}$ & 0.253 & -0.101 & $\underline{0.838}$ & 0.055 & -0.264 \\
$\mathrm{X}_{4}$ & 0.365 & 0.276 & $\underline{0.707}$ & -0.102 & 0.339 \\
$\mathrm{X}_{5}$ & -0.101 & -0.030 & -0.143 & $\underline{0.928}$ & -0.041 \\
$\mathrm{X}_{3}$ & 0.033 & 0.004 & 0.104 & $\underline{0.910}$ & 0.016 \\
$\mathrm{X}_{7}$ & 0.191 & 0.155 & -0.086 & $\underline{0.853}$ & -0.177 \\
$\mathrm{X}_{1}$ & -0.165 & -0.124 & -0.010 & -0.140 & $\underline{0.944}$ \\
\hline
\end{tabular}

Table 4 Substantial Factor Loadings (Varimax)

\begin{tabular}{|c|c|c|c|}
\hline Factor & Variable & Description & Loadings \\
\hline \multirow[t]{6}{*}{ Factor 1} & $\mathrm{X}_{13}$ & Number of communication facilities per settlement & 0.879 \\
\hline & $\mathrm{X}_{19}$ & Number of financial institutions per settlement & 0.869 \\
\hline & $\mathrm{X}_{12}$ & Number of social institutions per settlement & 0.859 \\
\hline & $\mathrm{X}_{9}$ & Percentage of households with formal education & 0.769 \\
\hline & $\mathrm{X}_{14}$ & Percentage of households with non-formal education & -0.729 \\
\hline & $\mathrm{X}_{11}$ & Number of administrative facilities per settlement & 0.550 \\
\hline \multirow[t]{6}{*}{ Factor 2} & $\mathrm{X}_{18}$ & Percentage of households with electric fan & 0.859 \\
\hline & $\mathrm{X}_{17}$ & Percentage of households with electric iron & 0.855 \\
\hline & $\mathrm{X}_{15}$ & Percentage of households with radio & 0.796 \\
\hline & $\mathrm{X}_{8}$ & Number of settlements connected to National Grid (electricity) & 0.773 \\
\hline & $\mathrm{X}_{16}$ & Percentage of households with TV set & 0.734 \\
\hline & $\mathrm{X}_{10}$ & Percentage of households with refrigerator & 0.691 \\
\hline \multirow[t]{4}{*}{ Factor 3} & $\mathrm{X}_{20}$ & Number of recreational facilities per settlement & 0.895 \\
\hline & $\mathrm{X}_{6}$ & Number of water facilities per settlement & 0.840 \\
\hline & $\mathrm{X}_{2}$ & Number of health facilities per settlement & 0.838 \\
\hline & $\mathrm{X}_{4}$ & Number of educational facilities per settlement & 0.707 \\
\hline \multirow[t]{3}{*}{ Factor 4} & $\mathrm{X}_{5}$ & Distance in $\mathrm{Km}$ travelled to reach the educational facilities & 0.928 \\
\hline & $X_{3}$ & Distance in $\mathrm{Km}$ travelled to reach the health facilities & 0.910 \\
\hline & $\mathrm{X}_{7}$ & Distance in $\mathrm{Km}$ travelled reach the water facilities & 0.853 \\
\hline Factor 5 & $\mathrm{X}_{1}$ & Road density in $\mathrm{Km}^{2}$ & 0.944 \\
\hline
\end{tabular}


Factor 2 on the other hand, accounts for $23.373 \%$ of the total variance and exhibits high positive loadings on households' ownership of electric fan (0.859), electric iron (0.855), radio (0.796), television set (0.734), refrigerator (0.691) and availability of electricity (0.773). This factor emphasized ownership of electrical appliances for the welfare of the households. The relationship between the households with these electrical appliances and availability of electricity is also articulated by this factor. Consequently, this factor has been termed Households' infrastructure. Factor 3 explains $17.610 \%$ of total variance and with significant positive loadings on recreational (0.895), water $(0.840)$, health $(0.838)$ and educational $(0.707)$ facilities. The availability of these infrastructures which can be classified as welfare infrastructure in the selected settlement is also articulated by this factor and is therefore labeled as Welfare infrastructure.

Factor 4 accounting for $13.741 \%$ of total variance is basically emphasizing distances covered by households to reach locations of basic infrastructure such as health, education and water facilities. It loads highly positive on three variables namely distance in kilometers covered to reach educational $(0.928)$, health $(0.910)$ and water (0.853) facilities. This factor can be termed Accessibility factor. Factor 5 which accounts for $5.988 \%$ of total variance has high positive loading on road density. It has the highest factor loading of 0.944 among the variables indicating the importance of road facilities in the selected settlements. This factor can therefore be labeled as Road density. This analysis has established five dimensions on which the twenty-two rural settlements in Niger State may be classified namely Institutional infrastructure, Households infrastructure, Welfare infrastructure, Accessibility factor and Road density.

\section{Factor scores of infrastructure-induced pattern of socio-economic development in selected settlements}

In order to depict structural patterns and differences in infrastructure-induced socioeconomic development, factor scores for each settlement are entered in Table 5. These statistical results are then indicated cartographically in Figures 3 to 7. The essence of this approach is to examine the performance of each settlement with respect to identified five factors. This would provide an answer to the question of whether infrastructure provision has any relationship with socio-economic development of the settlements.

Factor 1 which is Institutional infrastructure indicated high positive scores on four settlements namely Paiko, Agwara, Wushishi and Maikunkele. It is evident from these scores that these settlements as indicated in Figure 3 were provided with Institutional infrastructure such as communication facilities (GSM masts), financial institutions (commercial and micro-finance banks), social institutions as well as administrative institutions (local government secretariats, courts, police stations and posts). These settlements are incidentally the headquarters of their respectively local government areas, hence the availability of these facilities. The high factor loadings exhibited by this factor on formal and non-formal education can be explained in terms of the residents in these settlements consisting of those with formal and non-formal education. Settlements that loaded very high negatively under this factor are Gbajibo, Rafin Gora and Kutiriko. This indicates very low or non-availability of Institutional infrastructure in these settlements. The possible explanation for this may not be unconnected with the remoteness of these settlements in terms of distance to local government headquarters.

Factor 2 which is the Households' infrastructure is depicted in Figure 4. This factor loaded positively high in six settlements namely Enagi, Gawu Babangida, Lemu, Sabo Wuse, Doko and Nasko. This is a measure of households' ownership of electric appliances such as radio, electric fan, electric iron, television set and refrigerator. It is important to note that majority of the respondents from these settlements admitted ownership of these electrical appliances. The availability of electricity as articulated by this factor can be explained by the fact that all the settlements that loaded positively high were connected to National Grid. Other settlements that 
loaded very high but negatively are Bangi, Mashegu, Agwara, Rafin Gora and Tunga Magajiya. Some of these settlements such as Bangi, Mashegu and Agwara were not connected to National Grid. Consequently, majority of the residents in these settlements did not admit ownership of electrical appliances because of absence of electricity except those that have electricity generating sets.

Factor 3 is Welfare infrastructure shows high positive scores on three settlements namely Kuta, Bangi and Doko. These settlements are shown in Figure 5. It is significant to note these settlements were provided with Welfare infrastructure such as recreational, water, health and educational facilities. Consequently, rural hospitals, primary and secondary schools, as well as boreholes were found in Kuta, Bangi and Doko. The possible explanation may not be unconnected with the fact that both Kuta and Bangi are currently headquarters of Shiroro and Mariga respectively while Doko was the headquarters of the defunct Doko local government area, hence the availability of these welfare infrastructure. Other settlements that loaded very high but negatively under this factor are Gulu, Nasko, Tegina, Enagi, Lemu and Gbajibo. Some of these settlements especially Gulu and Nasko did not have adequate welfare infrastructure provisions.

Accessibility factor is indicated in factor 4 . This factor shows high positive scores on four settlements namely Gbajibo, Enagi, Paiko and Rafin Gora. These settlements are shown in Figure 6 . These settlements are rated very high in terms of short distances their residents travelled to enjoy the services provided by educational, health and water facilities. The possible explanation may be availability of these facilities in these settlements hence the short distances travelled to access them. The settlements that loaded high negatively on this factor are Gulu, Lemu, Kutiriko, Wushishi and Tegina. This implies that the residents of these settlements travelled longer distances to access these basic facilities, indicating inadequate provision of the facilities.

Factor 5, which has been termed Road density, shows high positive scores on three settlements as shown in Figure 7. These are Tunga Magajiya, Doko and Maikunkele. These settlements were provided with road infrastructure especially good network of township roads. For example, Tunga Magajiya and Maikunkele have trunk A Federal roads, while Doko has a network of township roads. Some of the settlements that loaded high but negatively on this factor are Kutiriko, Baddegi, Gbajibo and Gawu Babangida.

\section{Conclusion and Recommendation}

The study revealed that the factor analysis employed was able to reduce the initial twenty (20) infrastructural and socio-economic variables to only five factors. Invariably, these five factors contributed $85.82 \%$ of the total variance and were interpreted as Institutional infrastructure, Households infrastructure, Welfare infrastructure, Accessibility factor and Road density respectively. These were determined based on the variables on which the factors loaded highly and their direction. It was observed that these factors were responsible for variation in infrastructureinduced pattern of socio-economic development in the selected settlements in the study area.

The concept of rural settlement development is related to the availability of infrastructure as well as the quality of life of rural dwellers. There is no doubt that the level of socio-economic development of settlements is a function of the services enjoyed by the people. Consequently, the study has revealed that provision of infrastructure has impact on socio-economic development of rural settlements in Niger, State. It is without doubt that with greater attention directed towards the improvement in the provision and maintenance of infrastructure in the rural settlements, the standard of living and quality of life of people in rural settlements would be greatly improved. 
Ethiopian Journal of Environmental Studies and Management Vol. 6 Supplement 2013

Table 5 Factor Scores on the selected settlements

\begin{tabular}{lccccc}
\hline Settlement & Factor 1 & Factor 2 & Factor 3 & Factor 4 & Factor 5 \\
\hline Agwara & 1.9465740 & -1.7827041 & -.4914999 & -.9897813 & .3942868 \\
Baddegi & .0383848 & -.2398217 & .0962440 & -.8509914 & -2.0935676 \\
Bangi & -.1862545 & -3.3006756 & .6403272 & -.2049217 & -.2132183 \\
Doko & .1066987 & .9643873 & .3340574 & -.7361471 & 1.2605297 \\
Enagi & -.3477440 & 1.1837395 & -.8006266 & 1.5553608 & .5491925 \\
Gawu Babangida & .3010484 & 1.0309842 & -.6166113 & -.6067797 & -1.1270864 \\
Gbajibo & -1.6835752 & .1056072 & -.7715564 & 2.1530559 & -1.3700038 \\
Gulu & .4625352 & -.3822131 & -1.4274015 & -1.7873197 & -.9272601 \\
Kuta & -.5908929 & .5070950 & 2.8309462 & -.3141265 & -.1020255 \\
Kutiriko & -1.1156841 & -.2471069 & -.4881640 & -1.3118800 & -2.2060653 \\
Lemu & -.0360097 & 1.0235241 & -.7719638 & -1.6015543 & -.4568826 \\
Maikunkele & .5886854 & .4638773 & -.3751574 & .1808434 & .9404682 \\
Mashegu & -.7707035 & -3.0509368 & .3381342 & -.2305661 & -.6458091 \\
Nasko & -.7556354 & .8400791 & -1.2308249 & -.6769128 & -.8537464 \\
Paiko & 2.1879926 & -.0911427 & .2590093 & 1.3324445 & -.2632860 \\
Rafin Gora & -1.5709883 & -.9834564 & -.3321503 & 1.2266312 & .2060101 \\
Sabon Wuse & -.1069573 & .8875627 & -.2194383 & .5996888 & -.2649238 \\
Sarkin Pawa & -.1462304 & -.3902225 & -.0520457 & .6838091 & -.1004138 \\
Tegina & -.7565248 & .4616934 & -.9040756 & -1.0062438 & .3770720 \\
Tunga Magajiya & -.6538350 & -.6456609 & -.6327145 & -.1690822 & 2.2107512 \\
Wawa & -.6882548 & .3927392 & -.0473385 & .5022410 & -.0345998 \\
Wushishi & .6329467 & -.3578323 & -.4028196 & -1.0393081 & .2574271 \\
\hline
\end{tabular}




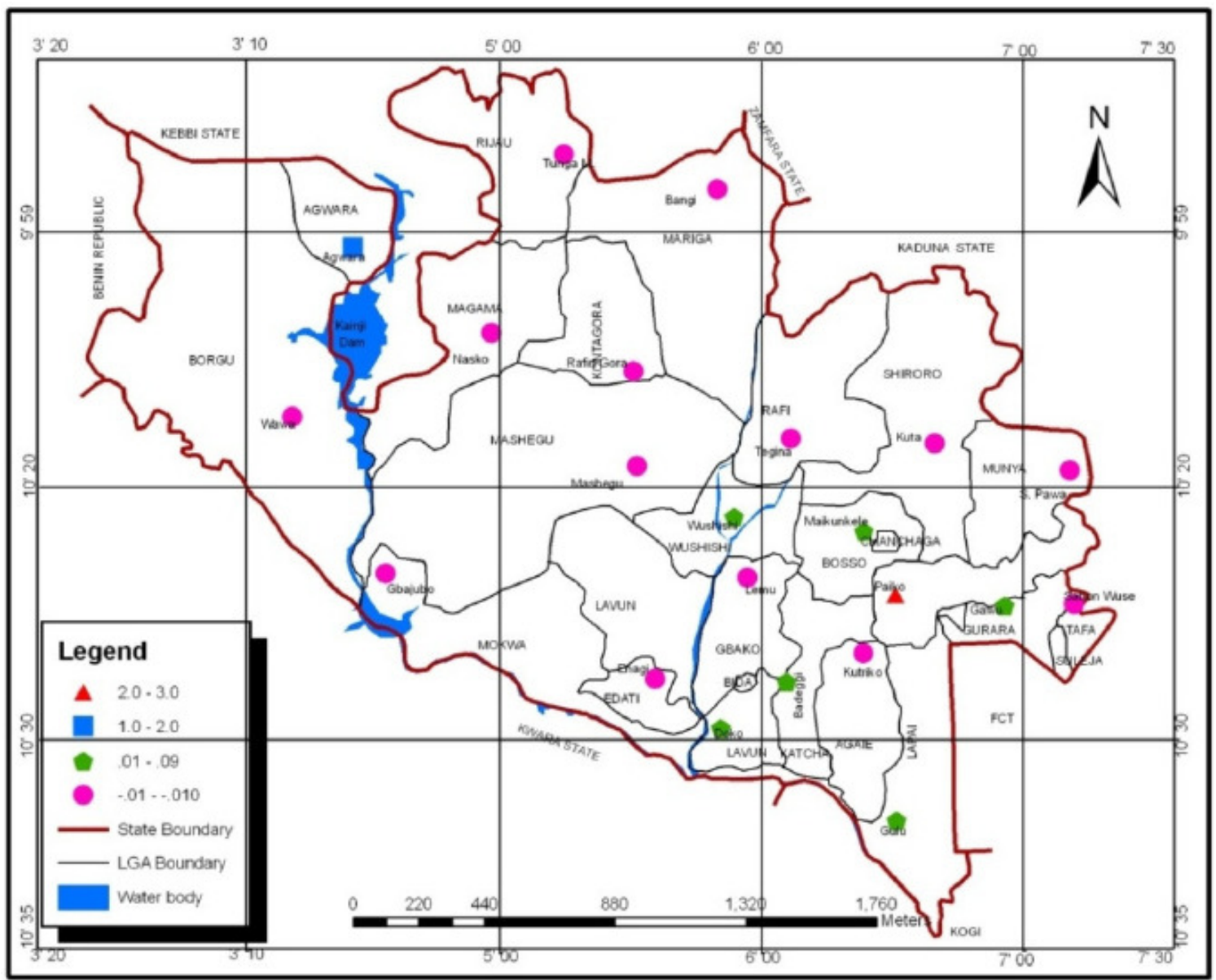

Figure 3 Pattern of Institutional Infrastructure (Factor 1) 


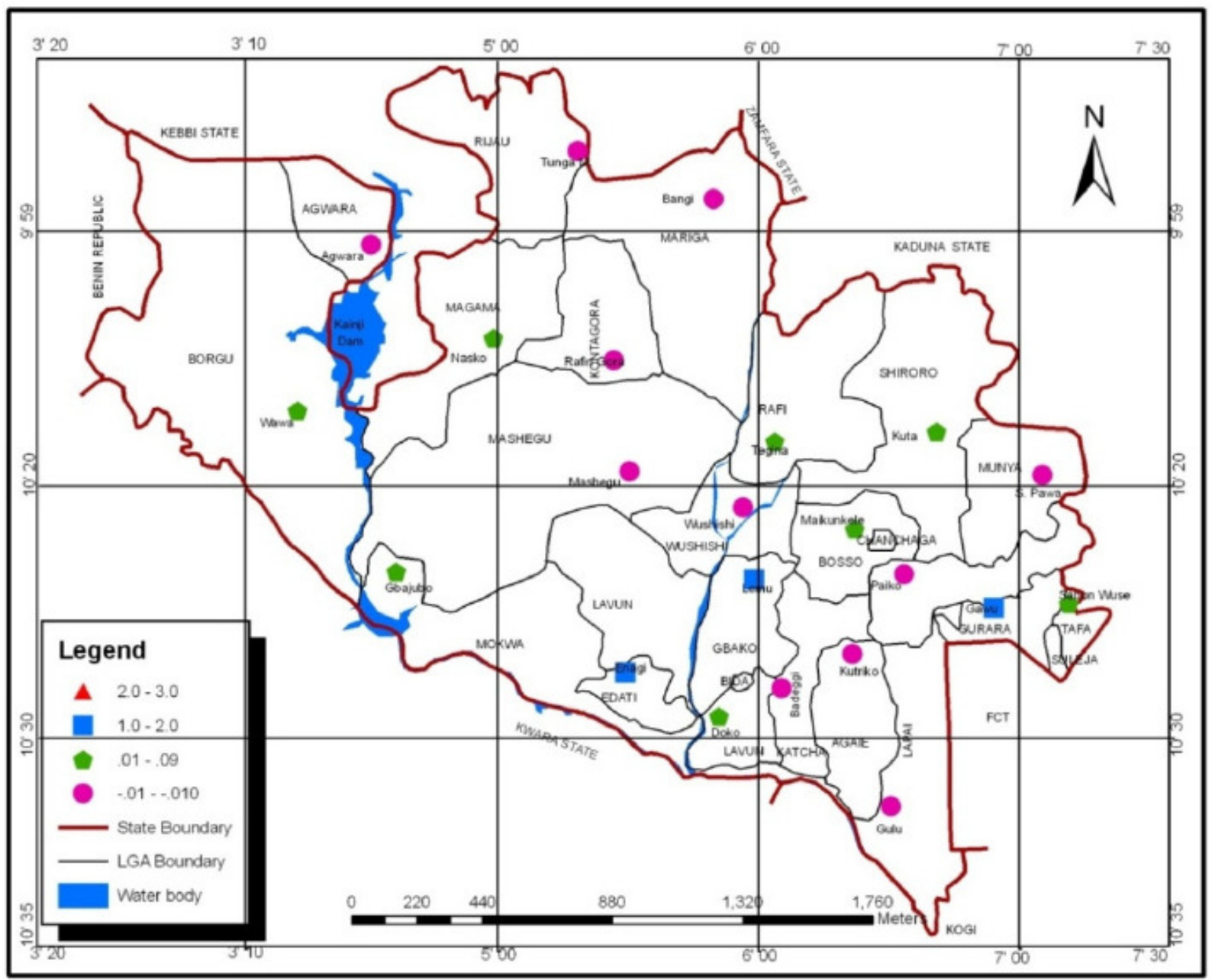

Figure 4 Pattern of Households' Infrastructure (Factor 2) 
Ethiopian Journal of Environmental Studies and Management Vol. 6 Supplement 2013

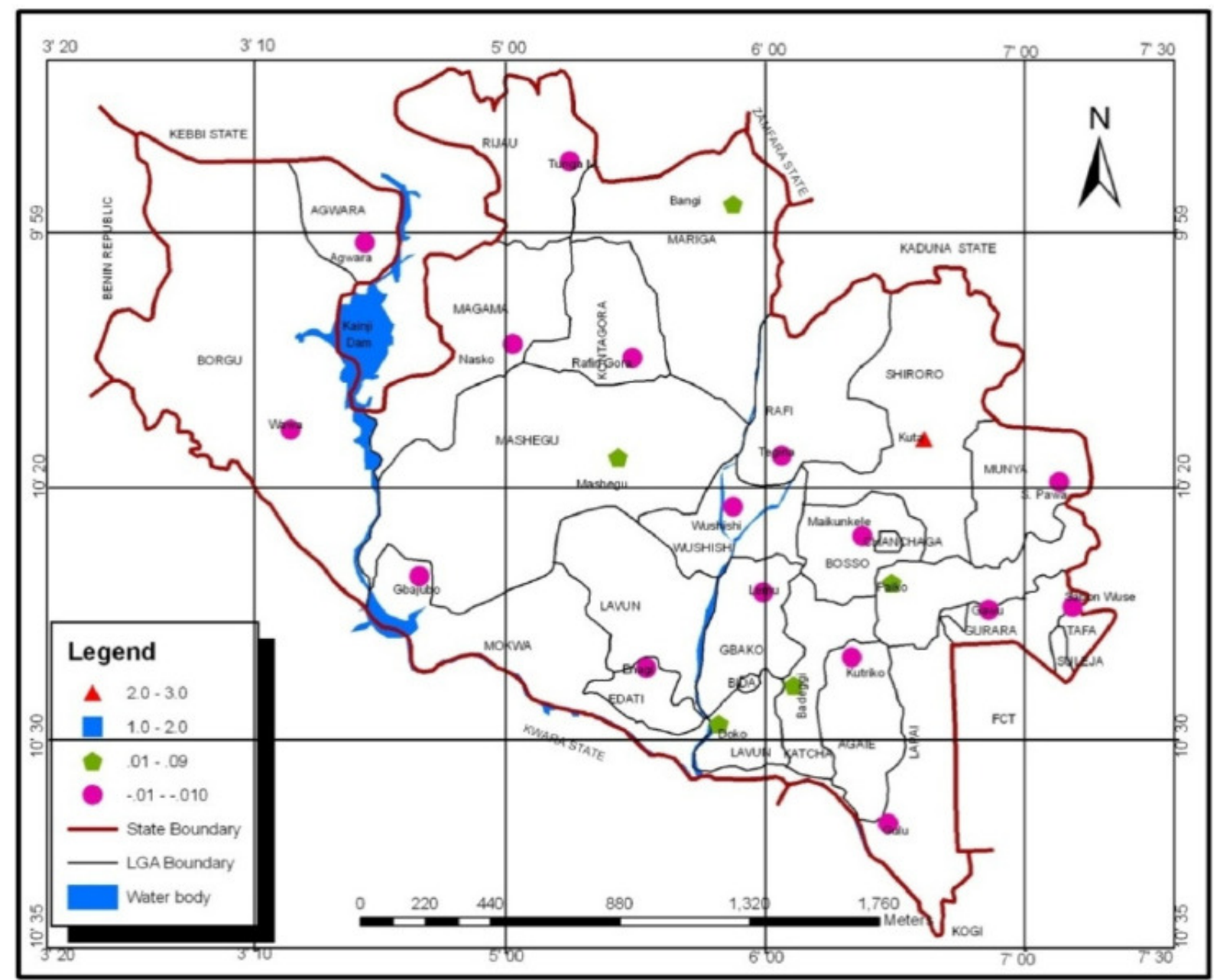

Figure 5 Pattern of Welfare Infrastructure (Factor 3) 


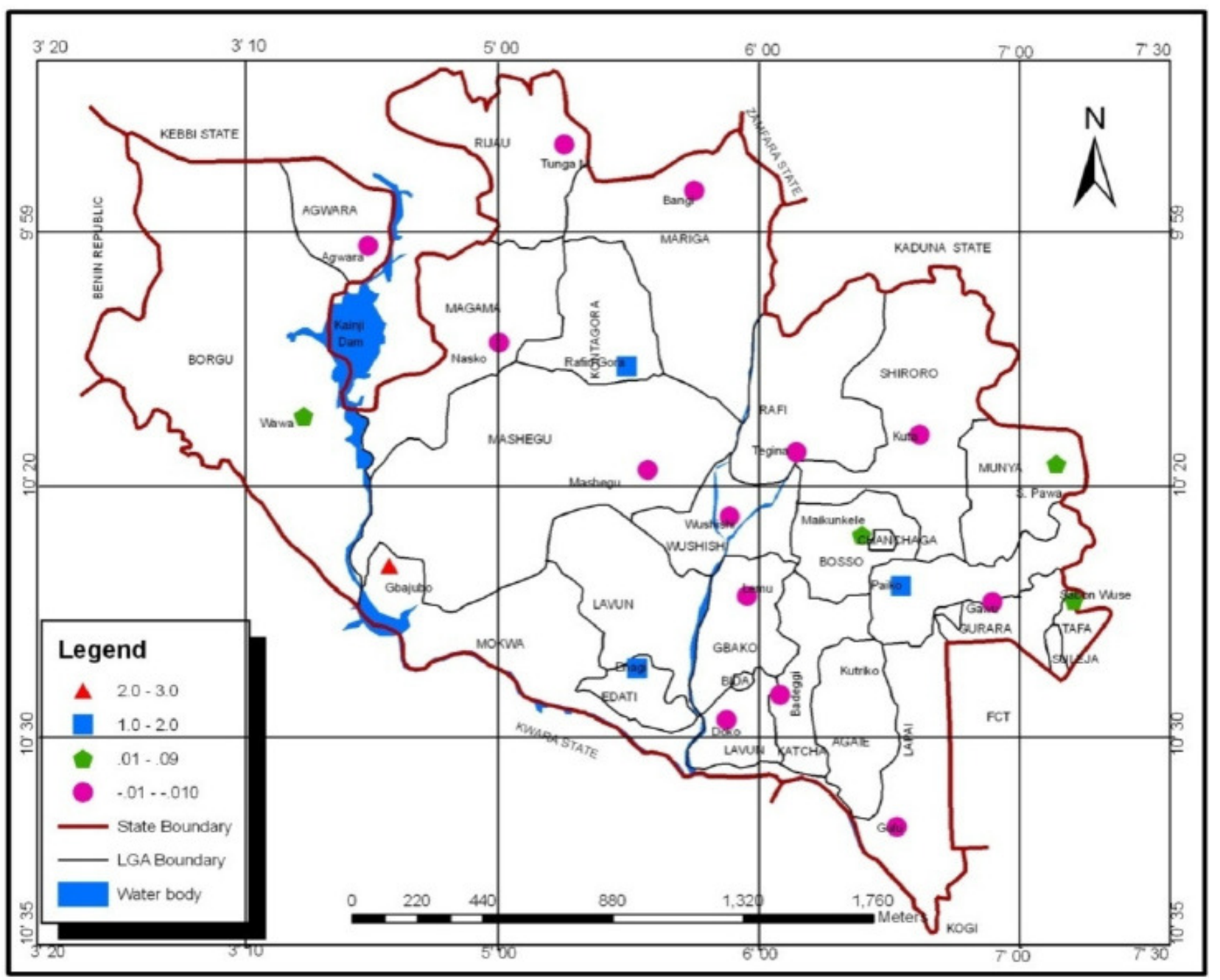

Figure 6 Pattern of Accessibility factor (Factor 4) 


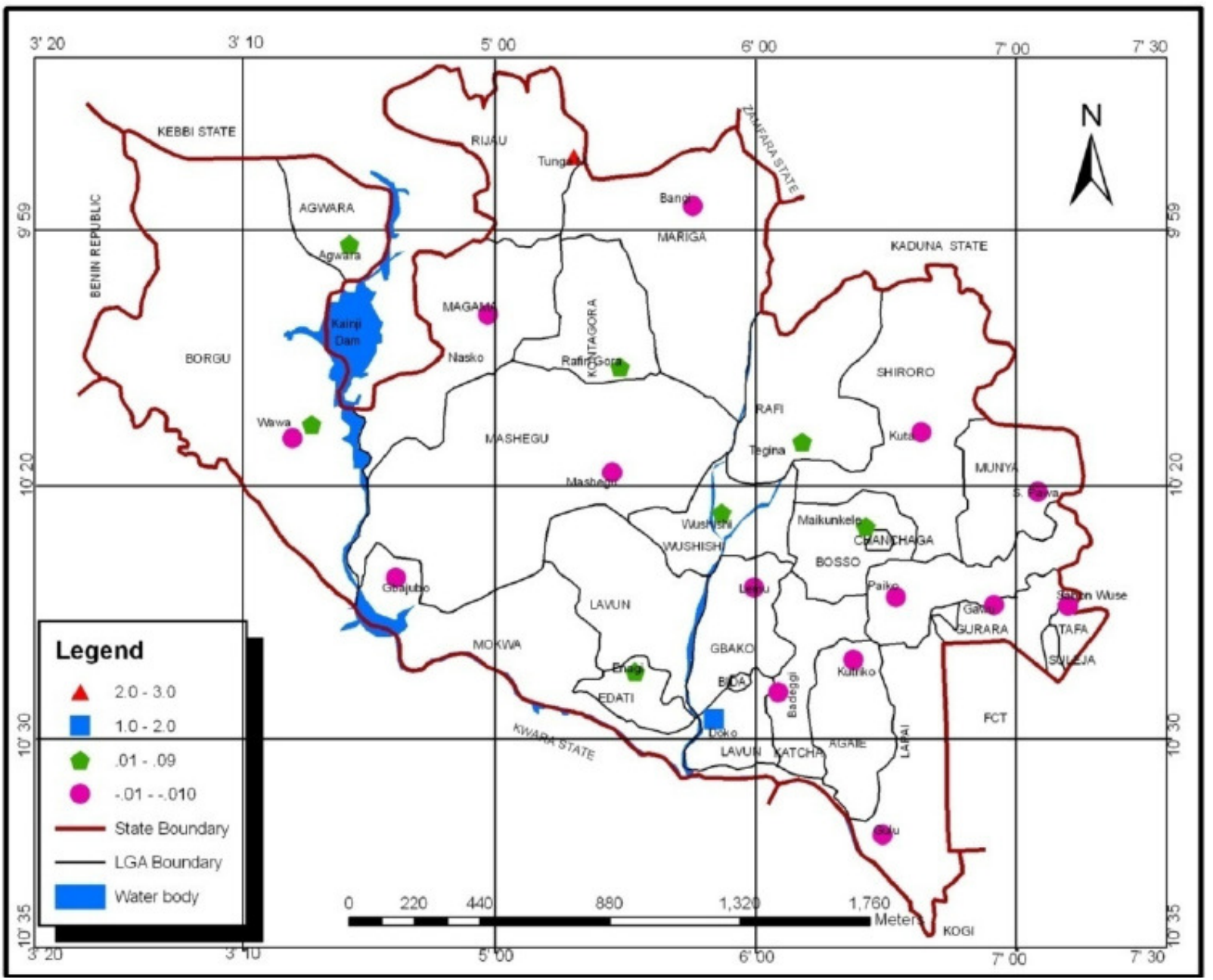

Figure 7 Pattern of Road density (Factor 5)

\section{References}

Abumere, S.I., Okafor, S.I. and Oluwasola, O. (2002), Rural Infrastructure and Development Process in Rural Nigeria. Research Report No. 36, Development Policy Centre. Ibadan, Nigeria. Adedayo, A. (1988), "Spatial Ecology of Social Deprivation in a Rural Nigeria Environment". International Journal of Environmental Studies. 31, 45-53.

Areola, O. (1987), "The concept and definition of Rural Infrastructure Development", Paper presented at the Workshop on Physical Planning and Rural Infrastructure Development in Nigeria organized by NISER, Ibadan.

Baba, J. M. (1993), "Niger State" in Udo, R.K and Mamman, A.B, (eds) Nigeria: Giant In The Tropics (Volume 2) Lagos: Gabumo Publishing Company Ltd.
Egunjobi, L. (1987), "Regional Approach to Rural Infrastructure Development Planning" Paper Presented at the Workshop on Physical Planning and Rural Infrastructure Development in Nigeria Organised by NISER, Ibadan, June 22-26, 1987.

Gana, J (1987), “ A strategy for Integrated Rural Development in Nigeria" Paper Presented at the National Workshop on Integrated Rural Development for Local Government Chairmen and State Directors of Rural Development Held at Durban Hotel Lagos, January 1987.

Madu, I.A. (2007), "The Underlying Factors of Rural Development patterns in the Nsukka Region of Southeastern Nigeria" Journal of Rural and Community Development 2, 110-122.

National Bureau of Statistics (2006), Core Welfare Indicator Questionnaire Survey, Nigeria, 2006. Abuja 
Niger State Government (2004), Niger Economic Empowerment and Development Strategy (NSEEDS), Ministry of Finance and Economic Planning, Minna.

Olujimi, J.B and Olanrewaju, T (2003), "The Concept of 'Top-Down' and 'Bottom-Up' Approaches to Rural Development: The Relevance and Plea for the Adoption in Nigeria"
International Journal of Environmental Issue. 1(1), 7-17.

Online Nigeria (2003), Nigeria: Niger State Online. Accessed on 29, April 2009 from http://www.onlinenigeria.com/links/Nigeradv.asp. 